\title{
EFESIENSI PENGAWASAN ATAS PENEGAKAN PERATURAN DAERAH KABUPATEN BADUNG NOMOR 3 TAHUN 1992 TENTANG JALUR HIJAU
}

\author{
I Wayan Winarsa \\ Fakultas Ilmu Sosial dan Ilmu Politik Universitas Mahendradatta - Denpasar \\ email: winarsawayan@gmail.com
}

\begin{abstract}
Abstrak- Penelitian ini dilatar belakangi oleh karena sudah lamanya Perda ini dan kala itu antara Kabupaten Badung dan Kota Denpasar masih satu, namun perda ini masih dipakai oleh Pemkab BadungTujuan dari penelitian ini, yaitu untuk mengetahui berapa besar masih layaknya perda ini diterapkan di Pemkab Badung. Hasil penelitian menunjukkan perlu adanya perda baru dalam rangka pengawasan atas penegakan peraturan daerah kabupaten Badung sebagai pengganti perda no 3 tahun 1992 tentang jalur hijau, karena pesatnya pemanfaatan jalur hijau sebagai daerah pemukiman.
\end{abstract}

Kata Kunci: Efisiensi, Pengawasan, Penegakan Perda, Jalur Hijau

Abstract- This research is motivated by the fact that this Regional Regulation and at the time between the Badung Regency and the City of Denpasar were still one, but this regulation was still used by the Badung Regency Government. The purpose of this study was to find out how much this local regulation was applied in the Badung Regency. The results of the study show that there is a need for new regulations in the context of monitoring the enforcement of the Badung regency regulation in lieu of regulation No. 3 of 1992 concerning green lanes, due to the rapid utilization of green lanes as residential areas.

Keywords: Efficiency, Monitoring, Enforcement of Regulations, Green Line

\section{Pendahuluan}

Negara Indonesia ini adalah negara yang berdasar atas hukum (rechtstaats) bukanlah atas kekuasaan (machststaat). Konsekuensi sebagai negara berdasarkan atas hukum adalah segala aparatur dari negara itu dalam menjalankan tugasnya harus berdasarkan atas hukum.

Salah satu ciri sebagai negara hukum adalah adanya perlindungan hukum bagi rakyat.Dengan begitu rakyat mendapat jaminan perlindungannya secara yuridis, sebagai warga negara yang mempunyai

Ida Bagus Made Satya Wira Dananjaya 
hak dan kewajiban, dimana pemerintah maupun pemerintah daerah tidak dapat melakukan tindakan sewenang-wenang terhadap rakyat sebaliknya rakyat tidak dapat melakukan kehendaknya menurut kepentingan pribadinya.

Dalam Undang-Undang Dasar 1945 beserta Amandemen ke- I dan II UUD 1945 di dalam Pasal 18 ayat 1, 2, dan 5 diatur mengenai Pemerintahan Daerah, yaitu:

1. Negara Kesatuan Republik Indonesia dibagi atas daerah-daerah Propinsi dan daerah Propinsi dibagi atas kabupaten dan kota mempunyai pemerintah daerah yang diatur dengan Undang-Undang.

2. Pemerintahan daerah Propinsi, Kabupaten, dan kota mengatur sendiri urusan pemerintahan menurut asas otonomi dan tugas pembantuan.

3. Pemda menjalankan otonomi seluasluasnya kecuali urusan pemerintahan yang oleh Undang-Undang ditentukan sebagai urusan pemerintah pusat.

Dari ketentuan diatas dapat disimak bahwa Negara Republik Indonesia merupakan Negara Kesatuan yang manamenganut asas desentralisasi di Ida Bagus Made Satya Wira Dananjaya dalam penyelenggaraan pemerintahan dengan memberi kesempatan dan keleluasaan, kepada daerah untuk menyelenggarakan Otonomi Daerah. Karena itu pasal 18 Undang-Undang Dasar 1945 antara lain, menyatakan bahwa pembagian daerah Indonesia atas daerah besar/kecil dengan bentuk dan susunan pemerintahannya ditetapkan dengan Undang-Undang.

Di dalam penjelasan pasal tersebut, antara laindikemukakan bahwa "oleh karena itu suatu eenheisstaat, maka Indonesia tidak akan mempunyai daerah dalam lingkungannya yang bersifat staat juga. Daerah Indonesia akan dibagi ke dalam Daerah Propinsi dan Daerah Propinsi akan dibagi dalam daerah yang lebih kecil. Di daerah-daerah yang bersifat otonom (Streek En Locale rechtgemeenschsppen) atau bersifat administrasi belaka, semuanya menurut aturan yang akan ditetapkan dengan Undang-undang”.

Dengan demikian adanya, UUD 1945 ini merupakan landasan yang kuat untuk menyelenggarakan otonomi dengan memberi kewenangan yang luas, nyata, dan bertanggung jawab kepada daerah sebagaimana tertuang dalam ketetapan MPR, RI Nomor XV/MPR/1998 tentang 
penyelenggaraan Otonomi Daerah; yang berkeadilan dan perimbangan Keuangan Otonomi Daerah; berkeadilan serta perimbangan Keuangan Pusat dan Daerah dalam kerangka NKRI.

Sesuai dengan Ketetapan MPR RI Nomor XV/MPR/1998 tersebut diatas, penyelenggaraan suatu otonomi daerah dilaksanakan dengan caramemberikan kewenangan yang luas, nyata dan juga bertanggung jawab kepada daerah secara proporsional yang diwujudkan kepada daerah dengan pengaturan, pembagian dan pemanfaatan sumber daya nasional yang berkeadilan, serta perimbangan keuangan pusat dan daerah. Disamping itu, penyelenggaraan otonomi daerah turut pula dilaksanakan dengan prinsipprinsip yang berdemokrasi, peran serta kalangan masyarakat, pemerataan dan keadilan,beserta memperhatikan potensi dan keanekaragaman daerah.

Hal mendasar dalam Undang-undang ini adalah mendorong memberdayakan masyarakat, menumbuhkan prakarsa dan kreativitas, meningkatkan peran serta masyarakat, mengembangkan peran dan fungsi DPRD.Oleh karena itu, Undangundang itu menetapkan Otonomi Daerah secara utuh pada Daerah Kabupaten dan Daerah. Daerah Kabupaten dan daerah kota tersebut berkedudukan sebagai Daerah Otonomi memiliki kewenangan dan keleluasaan untuk membentuk dan melaksanakan kebijakan prakarsa dan aspirasi masyarakat.

Sesuai dengan UUD 1945 pasal 18 ayat 6 menyebutkan bahwa: Pemda berhak menetapkan peraturan daerah dan peraturan-peraturan lain untuk dapat melaksanakan otonomi dan tugas-tugas pembantuan.

Sesuai penjelasan diatas, Pemda Kabupaten Badung dalam melaksanakan tugasnya dibidang pemerintahan dan pembangunan menetapkan berbagai Perda. Dari banyaknya Perda Kabupaten Badung, satu diantaranya adalah Perda Kabupaten Badung Nomor 3 Tahun 1992 tentang Larangan Mendirikan Bangunan-bangunan pada jalur sebelah kiri dan kanan sepanjang jalan yang ditetapkan sebagai dasar jalur hijau dalam Kabupaten Badung. Bilamana latar belakang penetapannya adalah mengatur mengenai tata ruang untuk pembangunan, pengembangan pariwisata sehingga tercapai kehidupan masyarakat sehat dan tentram di Kabupaten Badung.

Akibat penetapan Perda tersebut, maka kepada masyarakat yang memiliki tanah pada daerah yang ditetapkan 
sebagai daerah jalur hijau dilarang mendirikan bangunan permanen maupun yang tidak permanen, yang tidak sesuai dengan fungsi atau kepentingan tanah tersebut (pasal 2 Perda Kab.Badung No. 3 Tahun 1992).Sedangkan untuk bangunan yang telah dibangun sebelum ditetapkan Perda itu, dilarang diperluas baik ke atas maupun kesamping oleh pemiliknya.dengan pelaksanaan Perda

\section{WEWENANG DAN PROSEDUR PEMBENTUKAN PERDA}

\subsection{Pengertian dan Jenis Wewenang}

Kamus umum Bahasa Indonesia yang disusun oleh W.J.S. Poerwadarmita, yang dimaksud dengan kewenangan adalah hak dan kekuasaan (untuk melakukan sesuatu).

Dalam kaitannya dengan Pemerintah Daerah, kewenangan Pemerintah Daerah disini maksudnya adalah hak dan kekuasaan yang dimiliki oleh Pemerintah Daerah untuk melakukan sesuatu.

Beberapa literatur ditemukan pendapat tentang kewenangan dan wewenang. Prajudi Atmosudirjo mengemukakan bahwa:

"Kita perlu membedakan antara kewenangan (authority, gezag) dan juga wewenang (competence, bevoegheid), walaupun dalam praktek pembedaannya sendiri tidak selalu itu saat ini maka, beberapa wilayah keberadaannya mulai diperbincangkan karena pemilik tanah pada daerah yang telah ditetapkan sebagai jalur hijau itu membuat bangunan untuk perumahan.

Berdasarkan latar belakang masalah diatas maka penulis tertarik untuk membahas masalah tentang "Penegakan Peraturan Daerah Kabupaten Badung No. 3 Tahun 1992 Tentang Jalur Hijau.

dirasakan perlu.Kewenangan adalah apa yang disebut kekuasaan formal, kekuasaan berawal dari kekuasaan legislatif (diberi oleh undang-undang) atau berasal dari kekuasaan eksekutif/administratif."

Kewenangan merupakan kekuasaan terhadap segolongan orang-orang tertentu atau terhadap sesuatu bidang pemerintahan (atau bidang urusan) tertentu yang bulat, sedangkan wewenang hanya mengenai sesuatu onderdil tertentu saja.Wewenang adalah kekuasaan untuk melakukan suatu tindakan hukum privat atau hukum pribadi (hukum perdata).

Menurut Philipus M. Handjon, istilah wewenang atau kewenangan itu digunakan sejajar dengan istilah beveoedgheid dalam konsep hukum publik. Dalam konsep hukum publik, wewenang atau kewenangan berkaitan dengan kekuasaan yaitu kekuasaan 
hukum (rechtsmacht).Sebagai unsur suatu konsep hukum publik wewenang atau kewenangan terdiri atas sekurang-kurangnya tiga buah komponen, yaitu pengaruh, dasar hukum, dan konformitas hukum.

Komponen pengaruh itu adalah bahwa penggunaan wewenang dimaksudkan untuk mengendalikan perilaku ialah bahwa penggunaan wewenang dimaksudkan untuk mengendalikan perilaku subyek hukum. Komponen dasar hukum, artinya wewenang selalu harus dapat ditunjuk dasar hukumnya.Komponen konfirmitas hukum, mengandung makna adanya standard wewenang, yaitu standard umum (semua jenis wewenang) dan juga standard khusus (untuk jenis wewenang tertentu).

Bahwa kekuasaan seringkali bersumber pada wewenang formal (formal authority), yang memberi wewenang atau kekuasaan kepada seseorang atau suatu pihak dalam suatu bidang tertentu (tanpa tahun:4). Dengan demikian, kekuasaan itu bersumber kepada hukum, yaitu ketentuan hukum yang mengatur pemberian wewenang.

Menyimak berbagai pandangan di atas dapatlah dikatakan bahwa kewenangan atau wewenang berkaitan dengan kekuasaan yang formal/legal yaitu kekuasaan bersumber dari ketentuan hukum serta kewenangan selalu berkenaan dengan tindakan hukum publik.
Kewenangan daerah sendiri mencakup kewenanganseluruh bidang pemerintahan, kecuali di dalam bidang politik luar negeri, pertahanan keamanan, peradilan moneter, dan fiskal, agama, serta kewenangan bidang lain. Kewenangan bidang lain disini meliputi kebijakan tentang perencanaan nasional dan pengendalian pembangunan nasional secara makro, dana perimbangan keuangan, sistem administrasi negara, dan lembaga perekonomian negara, pembinaan dan pemberdayaan SDM, SDA, serta teknologi tinggi yang bersifat strategis, konservasi dan standarisasi nasional.

Kewenangan pemerintahan yang mana diserahkan kepada daerah dalam rangka desentralisasi harus pula disertai dengan penyerahan dan pengalihan pembiayaan, sarana dan prasarana, serta sumber daya manusia sesuai dengan kewenangan yang diserahkan tersebut.Selain itu, kewenangan pemerintahan yang dilimpahkan kepada gubernur dalam rangka dekonsentrasi harus disertai dengan pembiayaan sesuai dengan kewenangan yang dilimpahkan tersebut.

Kewenangan propinsi sebagai Daerah Otonom mencakup kewenangan di dalam bidang pemerintahan yang bersifat lintas Kabupaten dan Kota, serta kewenangan sebagai Daerah Otonom termasuk juga kewenangan yang tidak atau belum dapat 
dilaksanakan Daerah Kabupaten dan Daerah

Kota. Kewenangan Propinsi sebagai wilayah

Administrasi mencakup kewenangan dalam

bidang pemerintahan yang dilimpahkan

kepada Gubernur selaku wakil Pemerintah.

Daerah berwenang mengelola sumber daya nasional yang tersedia di wilayahnya dan bertanggung jawab untuk memelihara kelestarian lingkungannya sesuai dengan peraturan perundang-undangan.

Kewenangan Daerah menyangkut pula di wilayah laut yang meliputi:

1. Eksplorasi, eksploitasi, konservasi, dan pengelolaan kekayaan laut sebatas wilayah laut tersebut.

2. Pengaturan kepentingan administratif.

3. Pengaturan tata ruang.

\subsection{Fungsi Peraturan Daerah Dalam Pelaksanaan Otonomi Daerah}

Perda mempunyai kedudukan strategis, karena diberikan landasan konstitusional yang jelas sebagaimana diatur dalam Pasal 18 ayat (6) Undang-Undang Dasar Republik Indonesia Tahun 1945.Perda memiliki beberapa fungsi, pertama sebagai suatu instrumen kebijakan untuk melaksanakan otonomi daerah dan tugas pembantuan sebagaimana amanat UUD RI Tahun 1945 dan Undang-Undang tentang Pemerintahan Daerah.Kedua,Perda sebagai penampung
4. Penegakan hukum terhadap hukum yang telah dikeluarkan oleh daerah atau yang dilimpahkan kewenanganya oleh Pemerintah; dan

5. Bantuan penegakan keamanan dan kedaulatan negara.

Kewenangan daerah kabupaten dan daerah kota mencakup semua kewenangan pemerintahan. Bidang pemerintahan yang wajib dilaksanakan oleh daerah kabupaten dan daerah kota meliputi pekerjaan umum, kesehatan, pendidikan dan kebudayaan, pertanian, perhubungan, industri dan perdagangan, penanaman modal, lingkungan hidup, pertanahan, koperasi dan tenaga kerja.

kekhususan dan keragaman daerah, serta penyalur aspirasi masyarakat daerah.Namun pengaturannya, tetap dalam kerangka NKRI berlandaskan Pancasila dan UUD 1945.Ketiga, berfungsi sebagai alat pembangunan dalam meningkatkan kesejahteraan daerah.Dan keempat, sebagai peraturan pelaksanaan dari peraturan perundang-undangan yang lebih tinggi. Perda memiliki fungsi yang sama dengan peraturan perundang-undangan.

Bagir Manan mengemukakan tentang fungsi peraturan perundang-undangan, yang 
dapat dibagi menjadi dua kelompok utama, yaitu:

\section{Fungsi Internal}

Fungsi Internal adalah fungsi pengaturan perundang-undangan sebagai sub sistem hukum (hukum perundang-undangan) terhadap sistem-sistem kaidah hukum pada umumnya secara internal, peraturan perundang-undangan menjalankan fungsi penciptaan hukum, fungsi pembaharuan hukum, fungsi integrasi pluralisme hukum, fungsi kepastian hukum.Secara internal, peraturan perundang-undangan menjalankan beberapa fungsi:
a. Fungsi penciptaan hukum
b. Fungsi pembaharuan hukum
c. Fungsi integrasi pluralisme sistem hukum
d. Fungsi kepastian hukum

\section{Fungsi Eksternal}

Fungsi eksternal adalah keterkaitan peraturan perundang-undangan dengan tempat berlakunya.Fungsi eksternal ini dapat disebut sebagai fungsi sosial hukum, yang di mana meliputi fungsi perubahan, fungsi stabilisasi, fungsi kemudahan.Dengan demikian, fungsi ini dapat juga berlaku pada hukum-hukum kebiasaan, hukum adat, atau hukum yurisprudensi. Bagi Indonesia, fungsi sosialakan lebih diperankan oleh peraturan perundang-undangan, karena lewat berbagai pertimbangan yang sudah disebutkan di muka. Fungsi sosial ini dapat dibedakan:

a. Fungsi perubahan

b. Fungsi stabilisasi

c. Fungsi kemudahan

Lahirnya sebuah Perda ini merupakan upaya pemerintah daerah dalam mengelola otonomi daerah yang sesuai amanat Undang Undang Pemerintahan Daerah Tahun 2014.Hal itu tentunya juga dimaksudkan untuk menentukan fram atau koridor hukum yang membatasi ruang gerak dari masyarakat agar tidak bersikap semaunya. Pembatasan yang dimaksud bukan untuk melakukan tindakan represif yang bertentangan dengan hak asasi manusia, akan tetapi produk hukum daerah tersebut untuk memberikan kepastian hukum kepada masyarakatnya agar mereka merasa terayomi, terlindungi, dan dipikirkan akan keberadaannya.

\section{PENGAWASAN DAN SANKSI \\ TERHADAP YANG MELANGGAR \\ PERATURAN DAERAH KABUPATEN \\ BADUNG NO. 3 TAHUN 1992 \\ TENTANG JALUR HIJAU}

\subsection{Faktor-Faktor Yang Mempengaruhi \\ Pelaksanaan Peraturan Daerah}


Kabupaten Badung No. 3 Tahun 1992

tentang Jalur Hijau

Pengertian jalur hijau dapat ditinjau dari segi harfiahnya/etimologi, dan gramatikal.Secara etimologi, jalur hijau terdiri dari gabungan dua kata yaitu jalur dan hijau. Menurut W.J.S. Poerwadarminta di dalam bukunya kamus Bahasa Indonesia, jalur hijau berarti ruang antara dua deret tanaman yang menunjukkan panorama menghijau.

Secara gramatikal diatur di dalam buku Pedoman Tentang Perencanaan Lingkungan Perumahan, jalur hijau yaitu jalur tanah yang akan dipertahankan dalam keadaan semula (biasanya pertanian) dan hanya beberapa jenis bangunan tertentu yang diperbolehkan ada di dalamnya, seperti rumah sakit, rumah pertanian.

Sedangkan menurut Peraturan Daerah Kabupaten Badung tentang larangan mendirikan bangunan-bangunan pada daerah jalur hijau di Kabupaten Badung.Jalur hijau adalah suatu garis hamparan tanah yang luas menghijau, yang ditetapkan oleh pemerintah daerah sebagai daerah yang tidak boleh dibangun.

\subsection{Faktor-Faktor Pendukung}

Pelaksanaan Peraturan Daerah

Kabupaten Badung No. 3 Tahun 1992

Tentang Jalur Hijau

Guna mengkaji faktor-faktor pendukung maupun penghambat pelaksanaan Peraturan Daerah tentang Jalur Hijau, penulis mendasarkan pada faktor-faktor yang mempengaruhi keefektifan suatu peraturan sebagaimana dikemukakan oleh Soerjono Soekanto dan Mustafa Abdullah, adapun faktor-faktor yangikut menentukan keefektifan suatu peraturan ini sejalan dengan faktor-faktor yang berpengaruh dalam penegakan suatu peraturan, yaitu mencakup:

1. Kaidah hukum atau peraturan itu sendiri, artinya apakah peraturan dimaksud dapat menciptakan suatu keamanan, ketertiban, kepastian hukum, beserta perlindungan kepada masyarakat.

2. Petugas yang melaksanakan/menegakkan peraturan, artinya apa petugas hukum itu telah mempunyai sifat serta sikap yang bertanggung jawab terhadap tugas dan kewajiban.

3. Fasilitas yang mendukung pelaksanaan atau menegakkan peraturan itu, artinya apakah fasilitas yang diperlukan untuk 
kelancaran pelaksanaan dari peraturan telah ada dan lengkap.

4. Adanya kesadaran serta kepatuhan masyarakat untuk melaksanakan secara konsekuen terhadap peraturan-peraturan yang dibebankan kepadanya.

Bilamana keempat tolok ukur itu kita hubungkan dengan pelaksanaan Perda Nomor 3 Tahun 1992 tentang jalur hijau itu, maka keempat faktor itu merupakan faktor pendukungnya. Hal ini disebabkan karena:

1. Bahwa pembuatan dari Peraturan Daerah Kabupaten Badung Nomor 3 Tahun 1992 tentang jalur hijau telah memenuhi syarat-syarat pembuatannya baik syarat yuridis, sosiologis, maupun filosofis, sehingga dapat memberikan perlindungan dan kepastian hukum, serta keamanan terhadap masyarakat.

2. Ditinjau dari pelaksanaan/penegakkan peraturan daerah, dalam pelaksanaannya telah dibentuk Tim Pengawasan Izin Bangunan-Bangunan, Tim Pelaksana Izin Bangunan-Bangunan. Ketiga tim yang dibentuk itu merupakan unsur pembantu Kepala Daerah dalam tugasnya mencegah sekaligus pula menanggulangiterjadinya pelanggaran terhadap Perda Nomor 3 Tahun 1992. Disamping ketiga tim itu, Kepala Daerah juga dibantu oleh aparatur bawahannya seperti Camat, Kepala Desa, maupun oleh petugas penyidik pada umumnya. Dalam pelaksanaan tugasnya semua aparat di atas sampai saat ini telah melakukan berbagai tindakan untuk bisa mencegah serta menanggulangi terhadap rumah-rumah yang melanggar.

3. Sehubungan dengan fasilitas pendukung pelaksanaan dari Perda Nomor 3 Tahun 1992, selain telah tersedia perlengkapan administrasi kantor seperti mesin ketik, papan pengumuman, brosur-brosur, juga telah ada kendaraan "Boldozer". Palu, tali yang sewaktu-waktu siap dioperasikan untuk melakukan pembongkaran terhadap bangunan yang melanggar.

4. Ditinjau dari kesadaran dan kepatuhan masyarakat untuk dapat melaksanakan peraturan daerah Nomor 3 Tahun 1992, bahwasanya sebagian besar tidak merasa berkeberatan diterapkannya tanah-tanah yang mereka miliki sebagai kawasan jalur hijau, dan hanya sebagian kecil saja yang merasa keberatan. Alasan bagi mereka yang tidak berkeberatan adalah dengan penetapan sebagai kawasan jalur hijau, maka mereka akan tetap melaksanakan pekerjaannya sebagai petani tanpa ada dipengaruhi oleh timbulnya bangunan yang berpengaruh terhadap pengairannya. Alasan berkeberatan adalah oleh karena Ida Bagus Made Satya Wira Dananjaya 
penetapan itu mereka tidak dapat menjual tanahnya dengan harga tinggi ataupun

\subsection{Faktor-Faktor Penghambat}

\section{PelaksanaanPeraturan Daerah}

\section{Kabupaten Badung Tentang Jalur Hijau}

Dengan tetap berpijak terhadap keempat tolak ukur di atas, adapun faktor-faktor penghambat dalam pelaksanaan dari Perda Nomor 3 Tahun 1992 tentang jalur hijau adalah:

\section{Ditinjau dari segi peraturannya}

Dari penelitian yang penulis lakukan diperoleh informasi bahwa pembangunan rumah pemukiman oleh beberapa anggota masyarakat di kawasan jalur hijau itu disebabkan karena tanah di kawasan itu satu-satunya tanah yang mereka miliki, di lain pihak kemungkinan untuk hidup dalam lingkungan keluarga yang makin meningkat jumlahnya sudah tidak memungkinkan lagi. Sedangkan bagi mereka yang mendirikan bangunan untuk tempat berusaha, alasannya bahwa mereka mendirikan bangunan itu hanya untuk sementara waktu yang bersifat bangunan darurat.

Berkenaan dengan hal di atas apabila dihubungkan dengan isi dari Perda tentang jalur hijau tersebut, maka yang menjadi dasar kelemahan adalah mengenai wilayah tanahnya tidak dapat dibanguni untuk tempat usaha. berlakunya jalur hijau dan kepastian hukum mengenai bangunan-bangunan yang telah didirikan di kawasan jalur hijau tentu perlu ditinjau kembali apakahpada saat ini masih pantas dan sesuai dengan tata guna tanah serta kepentingan masyarakat? Sedangkan mengenai kepastian hukum dari rumusan "bangunan-bangunan" yang permanen atau tidak permanen, serta bangunan yang sesuai dengan fungsi atau kepentingan tanah perlu mendapatkan penegasan lebih lanjut untuk mencegah penafsiran yang berbeda-beda. Dengan kata lain ada beberapa materi dari peraturan daerah itu yang disesuaikan atau disempurnakan.

\section{Ditinjau dari petugas yang melaksanakan peraturan}

Pada prinsipnya aparat pelaksana dari Perda, yakni Kepala Daerah beserta aparat pembantunya telah melaksanakan tugas dan kewajiban mereka dengan baik. Hanya saja upaya pencegahan pelanggaran peraturan itu perlu lebih ditingkatkan sehingga dapat dikurangi penindakan terhadap bangunan yang telah jadi ataupun setengah jadi. Dan wajib untuk memasyarakatkan Peraturan Daerah ini baik melalui penyuluhan maupun 
penyebaran brosur-brosur perlu ditingkatkan lagi.

Semua hal di atas diperlukan untuk mengingatkan bahwa penindakan bangunan yang melanggar yang dilakukan sampai saat ini sebagian besar dilakukan terhadap bangunan yang sudah jadi ataupun setengah jadi yang sudah tentu menghabiskan biaya banyak. Dengan peningkatan pencegahan maka itulah prosedur serta biaya ataupun hubungan harmonis antara aparat pelaksana peraturan masyarakat dapat terwujud sesuai dengan maksud peraturan daerah itu sendiri.

\section{Fasilitas yang mendukung pelaksanaan peraturan}

Dalam rangka mewujudkan maksud di atas, maka pengawasan terhadap pelaksana perda tersebut perlu ditingkatkan. Untuk meningkatkan pelaksanaan pengawasannya, diperlukan dukungan dari prasarana seperti mobil keliling, ataupun sistem informasi yang cepat sehingga mampu dicegah dan ditanggulangi sedini mungkin pelanggaran yang akanterjadi. Disamping itu, sarana penginformasian Perda Nomor 3 Tahun 1992 pada wilayah jalur hijau seperti rehabilitasi papan pengumuman tentang ditetapkannya suatu wilayah sebagai kawasan jalur hijau sangat diperlukan.

Beberapa hal di atas perlu ditingkatkan, karena timbulnya pelanggaran atas Perda jalur hijau, ada yang mengemukakan karena sarana untuk melakukan pengawasan secara intensif (seperti mobil keliling), ataupun yang berpendapat bahwa pada saat mereka membangun di wilayah itu tidak dijumpai petunjuk papan pengumuman sebagai daerah jalur hijau.

\section{Ditinjau dari kesadaran dan kepatuhan masyarakat}

Secara keseluruhan dari para pemilik tanah yang ditetapkan tanahnya sebagai daerah jalur hijau belumlah memahami dengan baik isi daripada Peraturan Daerah Nomor 3 Tahun 1992. Hal ini karena masih terjadinya pelanggaran pada kawasan jalur hijau. Pada umumnya masyarakat hanya mengetahui bahwa di wilayah-wilayah yang ditetapkan sebagai kawasan jalur hijau tidak boleh membangun. Sedangkan, mengenai bangunan apa saja yang dilarang, bagaimana aturan hukum yang ditimbulkan terhadap pelanggaran larangan itu belumlah secara jelas diketahui masyarakat. Hal ini terutama terjadi pada para petani pedesaan yang jauh dari perkembangan kota.

Minimnyainformasi yang jelas dan tegas mengenai perda pada sebagian warga masyarakat, membuat muncul pelanggaranpelanggaran terhadap pelaksanaan peraturan itu. Hal ini mempengaruhi tingkat kepatuhan Ida Bagus Made Satya Wira Dananjaya 
masyarakat terhadap Perda Nomor 3 Tahun

\section{Pelaksanaan dan Pengawasan}

Terhadap Perda Kabupaten Badung No.

3 Tahun 1992 tentang Jalur hijau

Pelaksanaan serta pengawasan di dalam penegakan Peraturan Daerah tentang Jalur Hijau di Kabupaten Badung dilakukan oleh Bupati selaku Kepala Daerah, serta instansi terkait, seperti Dinas Cipta Karya Camat, Kepala Desa,

Adapun bentuk-bentuk dari pengawasan pada Perda Nomor 3 Tahun 1992 tentang jalur hijau di Kabupaten Badung adanya pengecekan tim pengawas izin bangunan, yaitu Dinas Cipta Karya dan dilakukannya pengecekan keliling oleh Satpol PP. Pada kawasan yang ditetapkan sebagai kawasan jalur hijau.

Tindak lanjut pengawasan dari pihak pelanggar akan dikenakan ketentuan perda diancam hukuman pidana dengan hukuman kurungan selama-lamanya tiga bulan atau denda sebanyak-banyaknya Rp50.000,(lima puluh ribu rupiah) dan si pelanggar bisa dibawa ke Pengadilan.

Pemda berwenang membuat Perda yang berisikan norma-norma atau kaidah-kaidah bersifat mengikat masyarakat, serta berkewajiban untuk melaksanakan sendiri
1992.

norma-norma tersebut.Dalam pelaksanaan norma-norma dari Perda, diberi kewenangan untuk memaksakan norma-norma itu agar ditaati masyarakat.Adapun bentuk sanksi yang diatur oleh Perda Kabupaten Badung, yaitu berupa sanksi administrasi, berupa teguran lisan atau tertulis bagi si pelanggar yang mendirikan bangunan di kawasan jalur hijau.Bilamana dalam pengawasan terhadap peraturan diduga akan terjadi pelanggaran sesuai pasal 4 ayat 2 Perda Nomor 3 Tahun 1992 maka oleh Bupati akan diadakan pengecekan dan memberikan peringatan kepada yang bersangkutan. Dalam melakukan pengecekan Bupati berwenang untuk menunjuk pejabat penyidik baik polisi, jaksa, maupun kepala dinas PU Kabupaten Badung untuk melakukan penyelidikan. Bilamana dari hasil penyelidkan terbukti ada pelanggaran, maka oleh pejabat penyidik dapat dikeluarkan surat peringatan secara lisan kemudian disusul dengan secara tertulis kepada pihak yang melanggar. Dan surat peringatan itu ditembuskan Bupati Kepala Daerah. Selanjutnya Bupati memberikan juga peringatan secara tertulis kepada yang bersangkutan, yang intinya memerintahkan dalam waktu satu minggu sejak surat 
perintah itu diterima agar membongkar bangunannya yang terbukti melanggar. Jika surat peringatan baik yang pertama, kedua dan ketiga dari Bupati serta surat peringatan lainnya dari instansi terikat seperti : camat, dan kepala desa tidak diindahkan maka si pelanggar atas perintah Bupati diadakan pembongkaran bangun-bangunan yang melanggar di kawasan jalur hijau di Kabupaten Badung.

Adapun mekanisme penjatuhan sanksi hukum terhadap si pelanggar dari hasil penelitian yang dilakukan penulis lakukan diperoleh data bahwa aibat hukum yang diterapkan kepada pihak-pihak pelanggar Peraturan Daerah Nomor 3 Tahun 1992 di daerah Kabupaten Badung adalah pemberian peringatan tertulis ataupun si pelanggar serta tindakan pembongkaran bangunan yang melanggar peraturan, sedangkan mengenai penerapan sanksi pidana seperti hukuman kurungan selama-lamanya tiga bulan atau denda sebanyak-banyaknya Rp. 50.000,(lima puluh ribu rupiah). Sampai saat ini belum pernah diterapkan dan penerapan dari akibat hukum tersebut terhadap para pelanggar maupun bangun-bangunan yang melanggar sampai saat ini berjalan dengan baik dan belum ada hambatan yang dijumpai dalam menerapkan akibat hukum yang berupa tindakan pembongkaran tersebut.
Dengan kata lain terhadap pemerintah daerah diberikan wewenang untuk menegaskan peraturan daerah yang bersangkutan.

Sehubungan dengan pelaksanaan dari peraturan daerah Kabupaten Badung Nomor 3 Tahun 1992 tentang jalur hijau, adapun aparat pelaksanaannya adalah Kepala daerah. Kepala Daerah di dalam menjalankan tugas ini dibantu oleh unsur stafnya serta oleh tim yang dibentuk khusus untuk pelaksanaan tugas itu, serta oleh aparat pemerintah pusat atau Daerah yang terkait. Unsur pemerintah daerah yang membantu tugas kepala daerah ini seperti misalnya Bapeda, Dinas Daerah, Camat, Kepala Desa. Sedangkan mengenai tim yang dibentuk Kepala Daerah Kabupaten Badung dalam melakukan tugasnya melakukan peraturan, pengawasan dan penertiban peraturan tentang jalur hijau adalah :

1. Tim pengawas izin bangun-bangunan yaitu:

1) Memberikan pertimbangan kepada Bupati Kepala Daerah Kabupaten Badung dalam pemeriksanaan izin bangun-bangunan, pengawasan dan penertiban bangun-bangunan.

2) Mengdakan pengawasan terhadap pelaksana perizinan bangun-bangunan di Kabupaten Badung.

Ida Bagus Made Satya Wira Dananjaya 
2. Tim pelaksana izin bangun-bangunan yang bertugas untuk:

1) Memberi pertimbangan kepada Kepala Dinas PU Kabupaten Badung dalam menangani perizinan, pengawasan, dan penertiban bangun-bangunan.

2) Memproses data hasil penelitian atau pengecekan yang dilakukan oleh tim pelaksana lapangan izin bangunbangunan.

3) Mengadministrasikan permohonan izin bangun-bangunan.

4) Mengadakan pengecekan dan pengawasan terhadap rencana dan kegiatan pembangunan di Daerah Kabupaten Badung, termasuk mengawasi persyaratan izin bangunbangunan.

5) Melaporkan pelaksanaan tugasnya kepada tim pengawas izin bangunbangunan.

3. Tim pelaksana pembongkaran bangunbangunan yang mempunyai tugas sebagai berikut:

1) Melakukan atau melaksanakan tindakan pembongkaran bangunbangunan setelah menerima pemberitahuan dari Kepala Dinas PU Kabupaten Badung.
2) Melaporkan hasil pelaksanaan tugasnya kepada Bupati Kepala Daerah Kabupaten Badung.

Selanjutnya aparat pemerintah lainnya yang turut serta membantu pelaksanaan Peraturan Daerah ini adalah para penyidik seperti Polisi. Jaksa Tim Penyidik ini bersama-sama dengan Kepala Dinas Pekerjaan Umum Kabupaten Badung melakukan tugas penyidik terhadap bangunan yang diduga melanggar Perda Nomor 3 Tahun 1992 tentang Jalur Hijau.

Aparat pembantu Bupati Kepala Daerah Kabupaten Badung di atas dalam menjalankan tugas dan kewajibannya senantiasa di bawah koordinasi dari Bupati Kepala Daerah, mengingat tanggung jawab pelaksanaan dari penegakan peraturan itu berada sepenuhnya pada Kepala Daerah sebagai Pemimpin Pemerintahan Daerah. Dengan kata lain berwenang untuk mengambil tindakan pencegahan, penyelidikan, maupun tindakan pembongkaran terhadap suatu bangunan yang terbukti melakukan pelanggaran tentang jalur hijau berada pada tangan Bupati Kepala Daerah Kabupaten Badung. 
IV. Sanksi Terhadap Pelanggaran Perda

Kabupaten Badung No. 3 Tahun 1992 tentang Jalur Hijau

Sebelum membahas mengenai sanksi terhadap pelanggaran Perda No. 3 tahun 1992 ada beberapa rteori keadilan yang diterapkan, sesuai dengan teori Keadilan untuk menganalisa pelaksanaan didalam penegakkan Perda No. 3 tahun 1992. Rawls adalah tokoh yang meyakini bahwa prinsipprinsip etika dapat menjadi dasar yang kuat dalam membangun masyarakat yang adil. Rawls mengembangkan pemikirannya tentang masyarakat yang adil dengan teori keadilannya yang dikenal pula dengan teori Posisi Asli. Dalam mengembangkan teorinya, Rawls banyak terpengaruh oleh aliran Utilitarianisme.

Mengenai pemikiran Rawls ini akan diuraikan lebih lanjut pada Bab V, tepatnya pada saat membahas tentang keadilan sebagai salah satu masalah-masalah filsafat hukum.

Rawls berpendapat perlu ada keseimbangan antara kepentingan pribadi dan kepentingan bersama. Bagaimana ukuran dari keseimbangan itu harus diberikan, itulah yang disebut dengan keadilan. Keadilan merupakan nilai yang tidak dapat ditawar-tawar karena hanya dengan keadilanlah ada jaminan stabilitas hidup mannusia. Agar tidak terjadi benturan kepentingan pribadi dan kepentingan bersama itu, perlu ada aturan-aturan. Di sinilah diperlukan hukum sebagai wasitnya. Pada masyarakat yang telah maju, hukum baru akan ditaati apabila ia mampu meletakkan prinsip-prinsip keadilan.

Rawls melihat, dalam kenyataannya, distribusi beban dan keuntungan sosial, seperti pekerjaan, kekayaan, sandang, pangan, papan, dan hak-hak asasi, ternyata belum dirasakan seimbang. Faktor-faktor seperti agama, ras, keturunan, kelas sosial, dan sebagainya, menghalangi tercapainya keadilan dalam distribusi itu. Rawls mengatakan, hal itu tidak lain karena struktur dasar masyarakat yang belum sehat. Untuk itu Rawls menganjurkan agar dilakukan reorganisasi (call for redress) sebagai syarat mutlak untuk menuju kepada suatu masyarakat ideal yang baru (Hujibers, 1988 : 195).

Menurut Rawls, kebutuhan-kebutuhan pokok meliputi hak-hak dasar, kebebasan, kekuasaan, kewibawaan, kesempatan, pendapatan, dan kesejahteraan. Jadi dalam kerangka dasar struktur masyarakat, kebutuhan-kebutuhan pokok (primary goods) terutama dapat dipandang sebagai sarana mengejar tujuan dan kondisi 
pemilihan yang kritis serta seksama atas tujuan dan rencana seseorang. Jika diterapkan pada fakta struktur dasar masyarakat, prinsip-prinsip keadilan harus mengerjakan dua hal:

1. Prinsip keadilan harus memberi penilaian konkret tentang adil tidaknya institusi-institusi dan praktik-praktik institusional.

2. Prinsip-prinsip keadilan harus membimbing kita dalam memperkembangkan kebijakankebijakan dan hukum untuk mengoreksi ketidakadilan dalam struktur dasar masyarakat tertentu.

Ada tiga syarat supaya manusia dapat sampai pada posisi aslinya, yakni:

1. Diandaikan bahwa tidak diketahui, manakah posisi yang akan diraih seorang pribadi tertentu di kemudian hari. Tidak diketahui mana bakatnya, intelegensinya, kesehatan, kekayaan, rencana hidupnya, keadaan psikisnya.

2. Diandaikan bahwa prinsip dari keadilan dipilih dengan semangat keadilan, yakni dengan keadilan untuk tetap berpegang pada prinsip-prinsip yang telah dipilih. Sikap ini perlu oleh karena sasaransasaran individual yang dituju harus dibagi rata antara banyak orang, dan pasti tidak semua orang akan menerima apa yang mereka inginkan. Sikap ini sebenarnya bertepatan dengan sikap rasional yang dapat diharapkan dari seorang yang bijaksana.

3. Diandaikan bahwa tiap-tiap orang pertama-tama suka mengejar kepentingan individualnya dan baru kemudian kepentingan umum.

Rawls mengakui kecenderungan manusia untuk mementingkan diri sendiri merupakan kendala utama dalam mencari prinsip-prinsip keadilan itu. Apabila dapat menempatkan diri pada posisi asli itu, manusia akan sampai pada dua prinsip keadilan yang paling mendasar sebagai berikut

1. Prinsip kebebasan yang sama sebesarbesarnya (principle of greatest equal liberty). Menurut prinsip ini setiap orang mempunyai hak yang sama atas seluruh keuntungan masyarakat. Prinsip ini tidak menghalangi orang untuk mencari keuntungan pribadi asalkan kegiatan itu tetap menguntungkan semua pihak.

2. Prinsip ketidaksamaan, yang menyatakan bahwa situasi perbedaan (sosial ekonomi) harus diberikan aturan sedemikian rupa sehingga paling menguntungkan golongan masyarakat yang paling lemah 
(paling tidak mendapat peluang untuk mencapai prospek kesejahteraan, pendapatan dan otoritas). Rumusan prinsip kedua ini sesungguhnya merupakan gabungan dari dua prinsip, yaitu prinsip perbedaan (different principle) dan prinsip persamaan yang adil atas kesempatan (the principle of fair equality of opportunity).

Secara keseluruhan, berarti ada tiga prinsip keadilan yang dikemukakan oleh Rawls, yaitu prinsip (1) kebebasan yang sama yang sebesar-besarnya, (2) perbedaan, dan (3) persamaan yang adil atas kesempatan. Tentu saja, tidak semua prinsipprinsip keadilan ini dapat diwujudkan bersama-sama karena dapat terjadi prinsip yang satu berbenturan dengan prinsip yang lainnya. Untuk itu Rawls memberikan prioritas.

Keadilan diberikan kepada masyarakat sebagai bentuk perlindungan hukum dalam Kamus Bahasa Indonesia adalah sebagai berikut: Kamus Bahasa Indonesia Kontemporer yang dimaksudkan dengan perlindungan hukum adalah: "Suatu upaya yang menjamin adanya kepastian hukum untuk memperoleh perlindungan berdasarkan peraturan-peraturan atau undang-undang".
Sedangkan menurut Kamus Hukum Perlindungan Hukum adalah: "Suatu upaya kepastian hukum untuk mendapatkan perlindungan berdasarkan peraturanperaturan yang dibuat oleh suatu kekuasaan negara dan sebagainya atau dapat yang berlaku bagi semua orang di suatu masyarakat atau negara".

Konsep perlindungan hukum atas suatu kepentingan tertentu, merupakan manifestasi dari prasyarat untuk masuk ke dalam phase Negara kesejahteraan. Fenomena Negara kesejahteraan (welfare state) merupakan fenomena penting di akhir abad ke-19 dengan gagasan bahwa Negara didorong untuk semakin meningkatkan perannya dalam mengatasi berbagai masalah yang dihadapi oleh masyarakat, termasuk masalah-masalah perekonomian yang dalam tradisi liberalisme sebelumnya cenderung dianggap sebagai urusan masyarakat sendiri.

Perlindungan tidak hanya berdasar hukum tertulis tetapi termasuk juga hukum tidak tertulis dengan harapan ada jaminan terhadap benda yang dimiliki dalam menjalankan hak dan kewajibannya. Hadjon menyebutkan, ada 2 macam perlindungan hukum bagi rakyat, yaitu:

1. Perlindungan Hukum Preventif: Kepada rakyat diberikan kesempatan mengajukan 
keberatan atau pendapatnya sebelum suatu keputusan pemerintah mendapatkanbentuk yang definitive. Bertujuan mencegah terjadinya sengketa.

2. Perlindungan Hukum Represif : bertujuan menyelesaikan sengketa

Perlindungan hukum preventif sangat besar artinya bagi pemerintah yang didasarkan kebebasan bertindak karena dengan ada perlindungan hukum preventif, pemerintah terdorong untuk bersifat hati-hati mengambil keputusan yang didasarkan pada diskresi.Dengan pengertian demikian, penanganan perlindungan hukum bagi rakyat oleh peradilan umum di Indonesia termasuk kategori perlindungan hukum represif.

Dari pengertian perlindungan hukum dalam penelitian ini penulis menggunakan acuan Perlindungan Hukum Represif.

Dalam kaitannya dengan pelanggaran Perda No. 3 tahun 1992 tentang jalur hijau. Pemerintah Daerah dalam kedudukannya sebagai pemegang hak eksekutif, harus selalu mengusahakan agar Peraturan Daerah itu ditaati bukan saja oleh rakyat tetapi juga oleh instansi-instansi pemerintah, dan bila dianggap perlu Pemerintah daerah dapat memaksakan penduduk untuk mentaati kaidah-kaidah itu, atau dengan kata lain
Pemerintahan Daerah berwenang untuk menegakkan Peraturan Daerah. Paksaan yang dilakukan oleh penguasa eksekutif untuk menegakkan hukum dalam UndangUndang ini disebut "paksaan penegakan hukum" atau "paksaan pemeliharaan hukum".

Paksaan itu harus didahului oleh suatu perintah tertulis oleh penguasa eksekutif kepada pelanggar. Apabila pelanggar tidak memperdulikannya, barulah dijalankan suatu tindakan yang memaksa. Paksaan itu harus langsung tertuju kepada pemulihan suatu keadaan atau pencegahan terjadinya suatu keadaan yang tidak sah. Pejabat yang diserahi tugas untuk menjalankan paksaan penegakan hukum terhadap pelanggar, oleh karena paksaan penegakan hukum itu pada umumnya dapat menimbulkan kerugian atau penderitaan, maka paksaan penegakan hukum itu hendaknya dilakukan secara cermat dengan memperhatikan berat ringannya pelanggaran yang dilakukan.

Penegakan Peraturan Daerah pada umumnya dilakukan dengan:

1. Mengambil atau meniadakan sesuatu, yang bertentangan dengan Peraturan daerah, dibuat atau ditiadakan; 
2. Mencegah segala sesuatu, yang bertentangan dengan Peraturan Daerah akan atau sedang dijalankan;

3. Melakukan segala sesuatu, yang bertentangan dengan Peraturan Daerah yang telah dipakai;

4. Memperbaiki segala sesuatu yang bertentangan dengan Peraturan Daerah telah ditiadakan.

Sehubungan dengan pentingnya Peraturan Daerah dalam penyelengaraan pemerintahan di daerah, maka di alam pembuatannya diperlukan persiapanpersiapan, pengetahuan dan penguasaan sepenuhnya materi yang akan diatur dalam Peraturan Daerah itu. Sehingga Peraturan Daerah nantinya benar-benar dirasakan manfaatnya oleh masyarakat atau instansi yang dikenakan peraturan itu. Untik itu hubungan serasi antara Kepala Daerah dan Dewan Perwakilan Rakyat Daerah sangatlah mendukung dalam proses pembuatan Peraturan Daerah tersebut.

Bilamana pengawasan terhadap peraturan itu diduga akan terjadi pelanggaran, sesuai dengan pasal 4 ayat 2 Perda Nomor 3 Tahun 1992 maka oleh Bupati diadakan pengecekan dan memberikan peringatan kepada yang bersangkutan. Dalam melakukan pengecekan Bupati berwenang untuk Pejabat Penyidik baik Polisi, Jaksa, maupun Kepala Dinas PU Kabupaten Badung melakukan penyidikannya. Bilamana dari hasil penyelidikan terbukti ada pelanggaran, maka oleh Pejabat Penyidik dapat dikeluarakan surat peringatan secara lisan yang kemudian disusul secara tertulis kepada pihak yang melanggar, dan surat peringatan itu ditembuskan kepada Bupati Kepala Daerah. Selanjutnya Bupati memberikan juga peringatan secara tertulis kepada yang bersangkutan, yang isinya memerintahkan agar dalam waktu satu minggu sejak surat perintah itu diterima agar membongkar bangunannya yang terbukti melanggar. Jika surat peringatan baik yang pertama, kedua, dan ketiga dari Bupati serta surat peringatan lainnya dari instansi seperti Camat, Kepala Desa, tidak diindahkan oleh si pelanggar, maka atas perintah Bupati diadakan pembongkaran bangun-bangunan Daerah Kabupaten Badung. Dan pembongkaran yang dilakukan oleh tim ini tidak disertai pemberian ganti kerugian kepada si pelanggar dan bahkan si pelanggar dapat dikenakan biaya pembongkaran tersebut.

Dari hasil penelitian yang penulis lakukan, diperoleh data bahwa akibat hukum yang diterapkan kepada pihak-pihak pelanggar Peraturan Daerah Nomor 3 Tahun 1992 di Ida Bagus Made Satya Wira Dananjaya 
Daerah Kabupaten Badung adalah pemberian peringatan tertulis ataupun lisan kepada si pelanggar, serta tindakan pembongkaran bangunan yang melanggar peraturan. Sedangkan mengenai penerapan sanksi pidana seperti hukuman kurungan selama-lamanya 6 bulan atau denda sebanyak-banyaknya Rp. 50.000,- sampai saat ini belum pernah diterapkan. Dan

\section{Kesimpulan}

Dari uraian pembahasan yang telah disampaikan pada bab sebelumnya, maka dapat ditarik kesimpulan sebagai berikut:

1. Kewenangan membuat peraturan perundang-undangan adalah kekuasaan yang melekat secara atributif kepada badan legislatif sebagai perwakilan seluruh rakyat yang berada di dalam lapangan hukum publik. Salah satu kewenangan organ Negara adalah kewenangan DPRD untuk membuat Peraturan Daerah. Kewenangan ini bersifat atributif, karena diberikan oleh UUD 1945 untuk DPR dan Undang Undang Nomor 23 Tahun 2014 tentang Pemerintahan Daerah untuk DPRD. Pembentukan Perda dalam rangka otonom daerah, harus dilakukan sesuai dengan mekanisme atau proses yang telah ditentukan di dalam Undang Undang penerapan dari akibat hukum tersebut terhadpa para pelanggar maupun bangunbangunan yang melanggar sampai saat ini berjalan dengan baik dan belum ada hambatan yang dijumpai dalam menerapkan akibat hukum yang berupa tindakan peringatan maupun tindakanpembongkaran tersebut.

Nomor 12 Tahun 2011 tentang Pembentukan Peraturan Perundangundangan. Di samping itu, juga harus mendasarkan pada asas-asas pembentukan peraturan daerah yang berlaku, mengingat asas merupakan roh atau nyawa dari sebuah peroduk perundang-undangan

2. Pengawasan terhadap pelaksanaan Perda Kabupaten Badung No. 3 Tahun 1992 tentang Jalur Hijau di wilayah-wilayah yang ditetapkan sebagai jalur hijau berjalan cukup efektif. Hal ini di dukung dengan dibentuknya tim pengawas izin bangunan, tim pelaksana bangunan dan tim pelaksana pembongkaran bangunbangunan. Selanjutnya bilamana terjadi pelanggaran terhadap Perda Nomor 3 Tahun 1992 maka akan dilakukan pembinaan terlebih dahulu, apabila tidak diindahkan, maka diberikan peringatan 
tertulis atau lisan kepada si pelanggar serta tindakan pembongkaran bangunan yang melanggar peraturan.

\section{Saran - Saran}

Berdasarkan simpulan di atas dapat disampaikan saran-saran sebagai berikut :

1. Untuk mencegah sedini mungkin timbulnya pelanggaran terhadap pelaksanaan Perda Nomor 3 Tahun 1992 tentang Jalur Hijau, disarankan agar pelaksanaan pengawasannya dilakukan secara intensif. Untuk itu kelengkapan

\section{DAFTAR PUSTAKA}

Amrah Muslimin, 1960, Ikhtisar Perkembangan Otonomi Daerah, Djambatan, Jakarta

Andi Mustari Pide, 1999, Otonomi dan Kepala daerah Memasuki Abad XXI, Cet. Kedua, Gaya Media Pratama

Ateng Syafrudin, 1973, Pemerintahan Daerah dan Pembangunan, Sumur ; Bandung

Atmaja, 2003, Ukum Antar Wewenang (Konsep dan Cara Penyelesaian), Makalah Lepas (bahan Kuliah S2) FH-UNUD, Denpasar

Bagir Manan, 1994, Hubungan Antara Pusat dan Daerah Menurut UUD 1945, (Jakarta, Pustaka Sinar Harapan Ketatanegaran Indonesia Menurut UUD 1945, Makalah disampaikan kepada Mahasiswa Pasca Sarjana, Unpad, , di Bandung sarana pendukungnya, pengawasannya serta keterlibatan aparat pemerintah perlu lebih ditingkatkan.

2. Agar masyarakat dapat mengetahui Perda Nomor 3 Tahun 1992 perlu lebih ditingkatkan baik dengan penyuluhanpenyuluhan, penyebaran brosur, rehabilitasi papan-papan pengumuman tentang Jalur Hijau yang telah rusak, sehingga niat untuk berspekulasi dengan larangan pendirian bangunan itu dapat dicegah.

Bayu Suryaningrat, 1981, Desentralisasi dan Dekonsentrasi Pemerintahan di Indonesia,, Dewaruci Press, Jakarta

Departemen Pendidikan dan Kebudayaan, 1998, Kamus Hukum

Djoko Prakoso, 1985, Proses Pembuatan

Peraturan Daerah Dan Beberapa Usaha Penyempurnaannya,Ghalia Indonesia, Yakarta

Hardjon M. Philippus, 1988. Perlindungan Hukum bagi Rakyat Indonesia, Bina Ilmu Surabaya.

Irawan Soejito,1984, Hub. Pemerintah Pusat dan Pemda, Bina Aksara,Yakarta

Jimly Asshiddiqie, 2000. Pergeseranpergeseran Kekuasaan Legislatif \& Eksekutif, Universitas Indonesia, Jakarta

Joharat Jayadinata, 1986, Tata Guna Tanah Dalam Perencanaan: Pedesaan, Perkotaan dan wilayah,ITB, Bandung 
Kansil, C,S,T, 1984, Hukum Tata Pemerintahan Indonesia, Ghalia Indonesia

Misdyanti dan Karta Sapoetra R.G.1993, Fungsi Pemerintah Daerah Dalam : Pembuatan Peraturan Daerah ,Bumi Aksara, Jakarta

Pamudji, 1983, Kepemimpinan Pemerintah di Indonesia, Cetakan Ketiga, Penerbit (Bina Aksara Jakarta

Philipus M. Hadjon dan Tatiek Sri Djatmiati,2001, Tata Perijinan Pada Era Otonomi Daerah, Makalah disampaikan pada symposium Nasional Sistem Kesehatan, di Surabaya, selanjutnya disebut Philipus M. Hadjon III,

Philipus M. Hadjon, , 1991, Peradilan Tata Usaha Negara, Tantangan Awal di Awal Penerapan UU No.5 Tahun 1986, Majalah FH Unair, No.2-3 Tahun VI, Surabaya, (selanjutnya disebut Philipus M.III

Philipus M. Hadjon, Dkk, 2002, Pengantar Hukum Aministrasi Indonesia (Introduction to the Indonesia Administrative), Cet. Ke-8, Gajah Mada Univ. Press, Yogyakarta

Poerwardarminta, W.J:S. 1976, Kamus Umum Bahasa Indonesia, Cet. V, (Jakarta, Balai Pustaka

Ridwan, HR.,2002, Hukum Administrasi Negara, UII-Press, Yogyakarta

Ronny Hanitijo Soemitro, 1990, Metodelogi Penelitian Hukum dan Jurimetri, Cet. IV, Ghalia Indonesia, Jakarta

Scehino,1980, Perkembangan Pemerintahan Di Daerah, Liberty, Yogyakarta

Sjahran Basah, 1986, Perlindungan Hukum terhadap Sikap Tindak Administrasi Negara, Orasi ilmiah pada Dies Natalis XXIX Unpad, Bandung, 24 September

Soerjono Soekanto dan Mustafa Abdullah,1983, Sosiologi Hukum
Dalam Masyarakat, CV Rajawali, Yakarta

Soesabdo Marmo Soedjono, 1984, Dkk, Mekanisme Pemerintahan di Daerah Beserta Peraturan Pelaksanaannya,PT. Twins

Tatirk Sri Diatmiati, 2002, Prinsip Izin Industri di Indonesia, Disertasi, Unair, Surabaya

The Liang Gie, 1968, Pertumbuhan Pemerintahan Daerah di Negara Republik Indonesia,Jilid 3 Gunung Agung Jakarta.

Thomas Subroto, 2000, Tanya Jawab Undang-Undang No.22 Tahun 1999 Pemerintahan Daerah, Dahara Prize Van Wijk, Dalam Bagir Manan, 1994, Dasar-Dasar Sistem Ketatanegaraan Indonesia Menurut UUD 1945, Makalah Ilmiah, Bandung Widiarta,2000, Kewenangan Administrasi Pajak Melakukan Penagihan Pajak dengan Surat Paksa,Lap. Peneiltian Unwar, Dnepasar

Kamus Bahasa Indonesia Kontemporer, 1991, Balai Pustaka, Jakarta 